\title{
ANALISIS PERBANDINGAN KINERJA PADA BANK NASIONAL DAN BANK ASING DENGAN MENGGUNAKAN ANALISIS RASIO KEUANGAN
}

\author{
Oleh:

\section{Christania Graciella Angel Rudy J. Pusung}

\author{
Program Pendidikan Profesi Akuntansi \\ Fakultas Ekonomi dan Bisnis \\ Universitas Sam Ratulangi Manado \\ Email : gangel_140890@yahoo.co.id
}

\begin{abstract}
ABSTRAK
Penilaian terhadap kinerja suatu bank tertentu dapat dilakukan dengan melakukan analisis terhadap laporan keuangannya. Laporan keuangan bank berupa neraca memberikan informasi kepada pihak di luar bank. Informasi yang diberikan mengenai gambaran posisi keuangannya, yang lebih jauh dapat digunakan pihak eksternal untuk menilai besarnya resiko yang ada pada suatu bank. Dilihat dari segi kepemilikannya, pengelompokkan bank dapat dibedakan atas 3 kelompok yaitu bank nasional, bank asing dan bank campuran. Ketiga kelompok bank ini dalam kenyataannya bersaing ketat untuk menunjukkan good performance di mata publik. Penelitian ini bertujuan untuk menganalis kinerja keuangan bank nasional dan bank asing periode 2004 - 2013 dengan menggunakan proksi keuangan (CAMEL) yang terdiri atas: Capital, Asset Quality, Management, Earnings, Liquidity. Populasi dalam penelitian ini adalah seluruh bank (bank asing dan bank nasional) yang tercatat dalam Bursa Efek Indonesia tahun 2004-2013 yang berjumlah 42 bank, dengan menggunakan purposive sampling jumlah sampel yang memenuhi kriteria adalah sebanyak 10 bank (dengan perincian 5 bank nasional dan 5 bank asing). Metode analisis yang digunakan adalah uji beda rata-rata $(t$-test). Dari hasil penelitian diperoleh penggunaan proksi CAMEL dalam melakukan analisis perbandingan kinerja memberikan bukti bahwa kinerja bank asing lebih baik dari bank nasional.
\end{abstract}

Kata Kunci : kinerja keuangan, bank nasional, bank asing, rasio CAMEL

\section{ABSTRACT}

Bank performance appraisal is based on bank financial report itself. The financial report can be form balance report which give information about the financial position to the outside of bank that can be used of eksternal to assess the level of risk exist in a bank. Based on ownership consist of national bank, mixture bank and foreign bank. These banks has tight compete to show a good performance to the public. This research aimed to analyze the financial performance difference of national bank and foreign bank at the period of 2004 to 2013 with the proxy finance ratio (CAMEL ratio) consist of: Capital, Asset Quality, Management, Earnings, and Liquidity. The population in this research consist of national bank and foreign bank listed on the Indonesia Stock Exchange at the period of 2004 to 2013 which amount 42 banks. Based on purposive sampling techniques, the number of samples that meet the criteria are as many as 10 banks (5 national banks and 5 foreign banks). Analysis technique that use in this research is t-test. As the result the usage of proxy CAMEL ratio to analyze comparison bank performance give evidence that foreign bank performance is better than national bank performance.

Keywords : financial performance, national bank, foreign bank, CAMEL ratio. 


\section{PENDAHULUAN \\ Latar Belakang}

Perekonomian Indonesia yang semakin terpuruk dewasa ini, seperti yang terlihat dari pertumbuhan ekonomi yang rendah, telah mengakibatkan persaingan antar perusahaan semakin ketat, khususnya bagi perusahaan yang memproduksi barang sejenis. Akibat positif dari persaingan ini adalah munculnya dorongan agar perusahaan meningkatkan daya saingnya, seperti dalam hal kualitas produk, kualitas pelayanan, efisiensi dan sebagainya. Salah satu bidang usaha yang menunjukkan persaingan yang ketat adalah bisnis perbankan.

Dampak krisis moneter yang terjadi mulai tahun 1997 terhadap industri perbankan di Indonesia adalah terjadinya negative-spread yaitu semakin besar perbedaan negatif antara sources dan uses of fund dan banyaknya debitur yang tidak mampu lagi membayar kewajibannya karena tingginya loan interest rate, mengakibatkan menurunnya kinerja perbankan di Indonesia. Sehingga banyak Bank Umum Swasta Nasional yang terkena penalti dari yang berbentuk take over sampai likuidasi (beku operasi) (Soendoro,2001). Penurunan kinerja bank-bank tersebut harus segera diperbaiki karena jika penurunan kinerja tersebut terus berlanjut tentunya akan membuat kredibilitas perbankan di mata masyarakat akan semakin menurun dan bagi bank-bank yang mengalami penurunan kinerja secara tajam tentu tinggal menunggu waktu untuk dilikuidasi jika tidak ada upaya untuk memperbaiki kinerjanya. Penilaian terhadap kinerja bank dapat dilakukan dengan melakukan analisis laporan keuangannya.

Ketentuan pelaksanaan penilaian tingkat kesehatan bank perlu diatur, sehubungan dengan hal tersebut penilaian mencakup faktor-faktor CAMEL yang terdiri dari: Permodalan (Capital), Kualitas Aset (Asset Quality), Manajemen (Management), Rentabilitas (Earnings), Likuiditas (Liquidity). Masalah yang timbul dalam penelitian ini bagaimanakah kinerja keuangan bank asing dan bank nasional yang terdaftar di Bursa Efek Indonesia periode 20042013 dilihat dari rasio CAMEL.

\section{Tujuan Penelitian}

Untuk menganalisis kinerja keuangan antara bank nasional dan bank asing yang terdaftar di Bursa Efek Indonesia periode 2004-2013 dilihat dari rasio CAMEL.

\section{TINJAUAN PUSTAKA}

\section{Landasan Teori}

Bank merupakan lembaga keuangan yang fungsi pokoknya memberikan kredit dan jasa-jasa dalam lalu lintas pembayaran dan peredaran uang. Oleh karena itu bank mempunyai ruang lingkup usaha yang luas. Pengertian bank menurut Undang-Undang Republik Indonesia No. 10 tahun 1998 tentang perbankan : (1) Pasal 1, perbankan adalah segala sesuatu yang menyangkut tentang bank, yang mencakup kelembagaan, kegiatan usaha, serta cara dan proses dalam melaksanakan kegiatan usahanya.; (2) Pasal 2, bank adalah badan usaha yang menghimpun dana dari masyarakat dalam bentuk simpanan dan menyalurkan kepada masyarakat dalam bentuk kredit dan atau bentuk-bantuk lainnya dalam rangka meningkatkan taraf hidup orang banyak; (3) Pasal 3, bank umum adalah bank yang melaksanakan kegiatan usaha secara konvensional dan atau berdasarkan prinsip syariah yang dalam kegiatannya memberikan jasa dalam lalu lintas pembayaran; (4) Pasal 4, Bank Perkreditan Rakyat adalah bank yang melaksanakan kegiatan usaha secara konvensional atau berdasarkan prinsip syariah yang kegiatannya tidak memberikan jasa dalam lalu lintas pembayaran.

Bank asing adalah bank umum yang didirikan dan dimiliki oleh pengusaha asing. Bank asing hanya dapat didirikan dan menjalankan usahanya sebagai bank setelah mendapat ijin usaha dari menteri keuangan. Bank ini didirikan dalam bentuk cabang dari bank yang 
sudah ada di luar negeri atau suatu bank asing dan bank nasional di Indonesia yang berbadan hukum Indonesia dan berbentuk Perseroan Terbatas.

Bank nasional terdiri dari bank-bank milik negara yang terdiri dari dari bank sentral dan bank umum milik negara, bank-bank milik pemerintah daerah yaitu bank-bank pembangunan daerah yang terdapat pada setiap Daerah Tingkat I, dan bank-bank milik swasta nasional yaitu bank-bank seluruh sahamnya dimiliki warga negara Indonesia dan atau badan-badan hukum yang peserta dan pemimpinnya terdiri atas warga negara Indonesia Suyatno (2007).

Analisis Rasio Finansial (Financial Statements Analysis) adalah alat-alat analisis yang digunakan untuk mengukur kinerja perusahaan di bidang keuangan. Analisa rasio memperhatikan kepada perhitungan rasio agar dapat mengevaluasi keadaan finansial pada masa yang lalu, sekarang dan memproyeksikan hasil yang akan datang. Rasio dapat dihitung berdasarkan financial statement yang telah tersedia yang terdiri dari : a) Balance sheet atau neraca, yang menunjukkan posisi perusahaan pada suatu saat. b) Income statement atau rugi laba yang merupakan laporan operasi perusahaan selama periode tertentu. Untuk mengetahui sejauh mana kondisi finansial perusahaan saat ini, diperlukan suatu cara evaluasi diantaranya; analisis historis (historical analysis) yang merupakan perkembangan antara suatu rasio saat sekarang dengan rasio yang sama pada waktu yang lampau, dan rasio industri yang merupakan rata-rata rasio yang dihasilkan dari beberapa perusahaan yang sejenis yang dapat dijadikan pembanding bagi perusahaan yang bersangkutan.

Penilaian tingkat kesehatan bank mencakup faktor-faktor CAMEL yang terdiri dari:

1. Permodalan (Capital Adequacy Ratio / CAR)

CAR merupakan rasio permodalan yang menunjukkan kemampuan bank dalam rangka pengembangan usaha dan menampung kemungkinan resiko kerugian yang diakibatkan kegiatan operasional bank. Penilaian aspek ini lebih dimaksudkan untuk mengetahui bagaimana atau berapa modal bank tersebut telah memadai untuk menunjang kebutuhannya. Apabila CAR perusahaan perbankan cukup tinggi, hal tersebut menunjukkan bahwa perusahaan perbankan tersebut memiliki kecukupan modal, sehingga kepercayaan masyarakat akan semakin meningkat. Apabila perusahaan perbankan telah go public, peningkatan kepercayaan itu tercermin melalui kenaikan harga sahamnya. Peningkatan harga saham akan meningkatkan nilai perusahaan dan return saham. Berdasarkan hal ini tampak hubungan yang signifikan antara CAR dengan resiko investasi pada saham perbankan. Perhitungan penyediaan modal minimum (CAR) didasarkan pada prinsip bahwa setiap penanaman dana bank yang mengandung resiko harus disediakan jumlah modal sebesar presentase tertentu dari jumlah penanamannya.

2. Kualitas Aset (Asset Quality)

Aktiva produktif merupakan sumber pendapatan utama dari kegiatan perusahaan perbankan. Yang termasuk komponen aktiva produktif di sini adalah kredit yang diberikan, penanaman modal dalam surat berharga, penanaman modal ke bank lain dan penyertaan. Pendapatan bank diharapkan semakin besar dari penanaman dalam aktiva produktif, sehingga kesempatan untuk memperoleh laba semakin meningkat. Perolehan laba akan memberikan penilaian positif bagi investor yang menanamkan modalnya pada saham perbankan. Dana yang berhasil dihimpun oleh bank akan menjadi beban bila dibiarkan saja. Oleh sebab itu bank harus mengalokasikan dananya dalam bentuk aktiva produktif. Penanaman dana bank pada aktiva produktif wajib dilaksanakan berdasarkan prinsip kehati-hatian. Pengurus bank harus menjaga kualitas aktiva produktifnya agar selalu dalam keadaan baik. Penilaian kualitas aktiva produktif diukur dengan menggunakan rasio Non Performing Loan (NPL), dan 
Penyisihan Penghapusan Aktiva Produktif (PPAP) terhadap aktiva produktif yang dimiliki bank.

Aspek ini diukur dengan menggunakan Non Performing Loan (NPL). Rasio NPL menunjukan bahwa kemampuan manajemen bank dalam mengelola kredit bermasalah yang diberikan oleh bank. Bank dalam memberikan kredit harus melakukan analisis terhadap kemampuan debitur untuk membayar kembali kewajibannya. Setelah kredit diberikan, bank wajib melakukan pemantauan terhadap penggunaan kredit serta kemampuan dan kepatuhan debitur dalam memenuhi kewajiban. Bank melakukan peninjauan, penilaian, dan peningkatan terhadap agunan untuk memperkecil risiko kredit. NPL mencerminkan risiko kredit, semakin kecil NPL, maka semakin kecil pula risiko kredit yang ditanggung pihak bank. Dengan demikian, apabila kondisi NPL suatu bank tinggi maka akan memperbesar biaya baik biaya pencadangan aktiva produktif maupun biaya lainnya sehingga berpotensi terhadap kerugian bank.

3. Manajemen (Management)

Penilaian kualitas manajemen suatu bank dapat dilakukan dengan menghitung rasio-rasio efisiensi usaha. Melalui rasio-rasio efisiensi usaha, tingkat efisiensi yang telah dicapai oleh manajemen bank yang bersangkutan dapat diukur secara kuantitatif. Manajemen yang dimaksud disini menunjukkan kemampuan manajemen bank untuk mengidentifikasi, mengukur, mengawasi, dan mengontrol risiko-risiko yang timbul melalui kebijakan-kebijakan dan strategi bisnisnya untuk mencapai target. Manajemen suatu bank diwajibkan mengelola banknya dengan baik sesuai dengan peraturan di bidang perbankan yang berlaku agar bank tersebut sehat.

Aspek ini diukur dengan menggunakan Net Interst Margin (NIM). Rasio NIM digunakan untuk mengukur kemampuan manajemen bank dalam mengelola aktiva produktifnya untuk menghasilkan pendapatan bunga bersih. Pendapatan bunga bersih diperoleh dari pendapatan bunga dikurangi beban bunga. Semakin besar rasio ini maka meningkatnya pendapatan bunga atas aktiva produktif yang dikelola bank sehingga kemungkinan suatu bank dalam kondisi bermasalah semakin kecil.

4. Rentabilitas (Earnings)

Earning merupakan kemampuan perusahaan perbankan untuk menghasilkan laba selama periode tertentu. Apabila rasio rentabilitas ini tinggi, maka hal ini menunjukkan bahwa perusahaan perbankan tersebut mampu meningkatkan usahanya melalui pencapaian laba operasi dalam periode tersebut. Perhitungan rentabilitas penting mengingat hanya bank yang memperoleh laba yang cukup yang dapat mengembangkan dirinya. Rentabilitas digunakan untuk mengukur keberhasilan manajemen menghasilkan laba melalui penanaman pada seluruh aktiva yang ada serta mengukur kemampuan bank dalam memperoleh pendapatan operasionalnya.

Aspek ini diukur dengan menggunakan Return On Assets (ROA). Analisis ROA digunakan untuk mengukur kemampuan perusahaan menghasilkan laba dengan total aset (kekayaan) yang dimiliki perusahaan setelah disesuaikan dengan biaya-biaya untuk mendanai aset tersebut. Total aset yang lazim digunakan untuk mengukur ROA sebuah bank adalah jumlah dari aset-aset produktif yang terdiri dari penempatan surat-surat berharga, penempatan dalam bentuk kredit. Semakin tinggi ROA akan semakin baik, karena untuk memperoleh ROA yang besar diperlukan adanya aktiva produktif yang berkualitas dan manajemen yang solid. Selain itu, semakin tinggi ROA, semakin besar pula kemampuan tingkat keuntungan yang dicapai bank sehingga kemungkinan suatu bank dalam kondisi bermasalah semakin kecil.

5. Likuiditas (Liquidity)

Likuiditas merupakan rasio yang mengukur kemampuan bank untuk memenuhi kewajiban keuangan yang harus segera dipenuhi. Kewajiban tersebut berupa call 
money yang harus dipenuhi pada saat adanya kliring, di mana pemenuhannya dilakukan dari aktiva lancar yang dimiliki perusahaan. Semakin besar aktiva lancar perusahaan perbankan maka semakin besar kemampuannya untuk memenuhi kewajibannya.

Aspek ini diukur dengan menggunakan Loan to Deposit Ratio (LDR). Rasio ini digunakan untuk menilai likuiditas suatu bank dengan cara membagi jumlah kredit yang diberikan oleh bank terhadap pihak ketiga. Semakin tinggi rasio ini, semakin baik tingkat kesehatan bank.

Ketentuan Bank Indonesia, bahwa kategori sehat dapat dikelompokkan dalam empat kelompok yang dapat dilihat pada tabel berikut ini :

Tabel 1. Tingkat Kesehatan Bank Menurut CAMEL

\begin{tabular}{|l|l|}
\hline Nilai Kredit CAMEL & Peringkat \\
\hline $81-100 \%$ & Sehat \\
\hline $66-81 \%$ & Cukup Sehat \\
\hline $51-66 \%$ & Kurang Sehat \\
\hline $0-51 \%$ & Tidak Sehat \\
\hline
\end{tabular}

Sumber: Kasmir, 2012

Faktor-faktor proksi rasio keuangan sesuai dengan bobotnya masing-masing dan dikuantitatifkan sesuai dengan ketentuan yang berlaku. Hasil penelitian dapat dikurangi dengan nilai kredit atas pelaksanaan ketentuan-ketentuan yang sanksinya dikaitkan dengan penilaian tingkat kesehatan bank. Berbagai ketentuan tersebut meliputi pelaksanaan pemberian Kredit Usaha Kecil (KUK), pelaksanaan pemberian kredit ekspor, pelanggaran terhadap ketentuan Batas Maksimal Pemberian Kredit (BMPK) dan pelanggaran terhadap Posisi Devisa Netto (PDN). Berdasarkan penilaian-penilaian tersebut akhirnya ditetapkan apakah bank tersebut termasuk dalam kategori sehat, cukup sehat, kurang sehat ataupun tidak sehat. Predikat tingkat kesehatan bank yang sehat atau cukup sehat atau kurang sehat akan diturunkan menjadi tidak sehat apabila terdapat :

1. Perselisihan intern yang diperkirakan akan menimbulkan kesulitan dalam bank yang bersangkutan.

2. Campur tangan pihak-pihak di luar bank dalam kepengurusan (manajemen) bank, termasuk di dalamnya kerjasama yang tidak wajar yang mengakibatkan salah satu atau beberapa kantornya berdiri sendiri.

3. Window dressing dalam pembukuan dan atau laporan bank secara materiil dapat berpengaruh terhadap keuangan bank sehingga mengakibatkan penilaian yang keliru terhadap bank, praktek bank dalam bank atau melakukan usaha bank di luar pembukuan bank.

4. Kesulitan keuangan yang mengakibatkan penghentian sementara atau pengunduran diri dari keikutsertaan dalam kliring.

\section{Penelitian Terdahulu}

Penelitian Clorinda (2013), yang berjudul Analisis Pengaruh Capital Ratio, Asset Quality, dan Liquidity Ratio terhadap kinerja keuangan pada sektor perbankan yang terdaftar di BEI periode 2007-2011, dengan menggunakan metode least square terlihat Terlihat bahwa DPK berpengaruh positif signifikan terhadap ROA. CAR dan PPAP terbukti berpengaruh negatif terhadap ROA. 
Penelitian Rumondor (2013), yang berjudul Perbandingan kinerja keuangan bank Mandiri, BRI, dan BNI yang terdaftar di BEI, dengan menggunakan uji t dan uji F diperoleh ketiga bank tersebut berada pada prseidkat cukup sehat dengan peringkat komposit berada pada PK-3.

Penelitian Hutagalung,Djumahir,Ratnawati (2011) yang berjudul Analisis rasio keuangan terhadap kinerja bank umum di Indonesia, dengan metode analisis regresi berganda diperoleh hasil NPL,NIM,BOPO berpengaruh signifikan terhadap kinerja yang diproksikan dengan ROA sedangkan CAR dan LDR tidak berpengaruh signifikan terhadap kinerja yang diproksikan ROA.

Penelitian Utomo (2008) yang berjudul Pengaruh NPL terhadap kinerja keuangan berdasarkan rasio likuiditas, solvabilitas, dan profitabilitas pada Bank Mandiri dengan menggunakan analisis korelasi dan regresi berganda diperoleh hasil: ada 5 variabel yang dipengaruhi NPL: Primary ratio, Capital ratio, CAR, NPM, dan Return on equity capital, sedangakn ada 7 variabel yang tidak dipengaruhi NPL: Quick ratio, Asset to loan ratio, Cash ratio, LDR, Rate return on loan, Interest margin on earning assets, dan Interest margin on loans.

\section{Kerangka Konseptual}

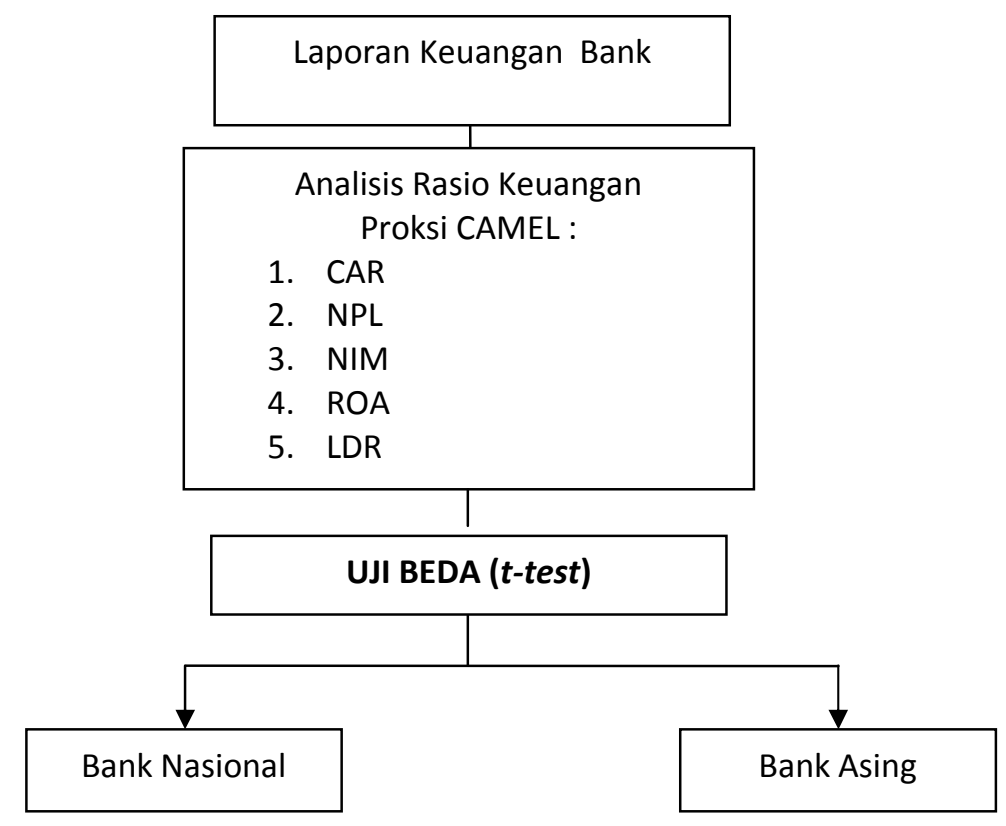

\section{Hipotesis Penelitian}

Berdasarkan rasio CAMEL, kinerja keuangan bank nasional dan bank asing yang terdaftar di BEI periode 2004-2013 berbeda signifikan.

\section{METODE PENELITIAN Jenis Penelitian}

Jenis penelitian yang digunakan pada penelitian ini adalah explanatory (penelitian penjelasan) yakni penelitian yang menyoroti hubungan antara variabel penelitian dan pengujian hipotesis yang dirumuskan sebelumnya.

\section{Populasi dan Sampel}

Populasi dalam penelitian ini adalah seluruh bank (bank nasional dan bank asing) yang tercatat dalam Bursa Efek Indonesia (www.idx.co.id) tahun 2004-2013, yang berjumlah 42 
bank. Sampel bank dipilih secara purposive sampling dengan pemilihan kriteria : merupakan perusahaan perbankan yang menerbitkan laporan keuangan sepuluh tahun berturut-turut dari tahun 2004-2013, dan laporan keuangan yang diterbitkan mempunyai tahun buku yang berakhir 31 Desember agar menghindari adanya pengaruh waktu parsial dalam perhitungan rasio keuangan. Berdasarkan kriteria tersebut maka jumlah sampel yang memenuhi kriteria adalah sebanyak 10 bank, dengan perincian : 5 bank nasional dan 5 bank asing.

\section{Metode Analisis}

Metode analisis yang digunakan dalam penelitian ini adalah penelitian kuantitatif dengan metode uji beda rata-rata ( $t$-test). Uji t merupakan jenis pengujian statistik untuk mengetahui apakah terdapat perbedaan dari nilai yang diperkirakan dengan nilai hasil perhitungan statistik. Syarat untuk melakukan uji-t antara lain : (1) Nilai parameter diketahui/ditentukan; (2) Distribusi normal. Uji yang digunakan dalam penelitian ini adalah independent-sample t test. Independent-sample $t$ test digunakan untuk menguji signifikansi beda rata-rata dua kelompok. Tes ini digunakan untuk menguji pengaruh variable independen terhadap variable dependen.

\section{Definisi Operasional dan Pengukuran Variabel}

Variabel yang digunakan dalam penelitian ini adalah menggunakan alat analisis metode CAMEL, yang terdiri atas:

1) Capital Adequacy Ratio / Permodalan

Capital Adequacy Ratio merupakan rasio permodalan yang menunjukkan kemampuan suatu bank dalam mengantisipasi kebutuhan akan tersedianya dana sendiri guna pertumbuhan usaha serta memikul resiko kerugian yang timbul dalam menjalankan usahanya yang diproksikan oleh CAR dan diperoleh dengan rumus :

$$
\mathrm{CAR}=\frac{\text { Modal bank }}{\text { Total ATMR }} \times 100 \%
$$

2) Asset Quality / Kualitas Aktiva Produktif

Kualitas Aktiva Produktif diproksikan dengan NPL. Rasio NPL menunjukkan bahwa kemampuan manajemen bank dalam mengelola kredit bermasalah yang diberikan oleh bank. NPL mencerminkan risiko kredit, semakin kecil NPL, maka semakin kecil pula risiko kredit yang ditanggung pihak bank. NPL diperoleh dengan rumus :

$$
\mathrm{NPL}=\frac{\text { Kredit bermasalah }}{\text { Total Kredit }} \times 100 \%
$$

3) Management / Manajemen

Aspek manajemen diproksikan dengan Net Interest Margin (NIM). Rasio NIM digunakan untuk mengukur kemampuan manajemen bank dalam mengelola aktiva produktifnya untuk menghasilkan pendapatan bunga bersih. Pendapatan bunga bersih diperoleh dari pendapatan bunga dikurangi beban bunga. Net Interest Margin (NIM) dihitung dengan rumus:

$$
\mathrm{NIM}=\frac{\text { Pendapatan bunga bersih }}{\text { Aktiva Produktif }} \times 100 \%
$$

4) Earning / Rentabilitas

Aspek Earning diproksikan dengan ROA (Retun On Assets). ROA digunakan untuk mengukur kemampuan perusahaan menghasilkan laba dengan total aset (kekayaan) yang dimiliki perusahaan setelah disesuaikan dengan biaya-biaya untuk mendanai aset tersebut. Semakin tinggi ROA, semakin besar pula kemampuan tingkat keuntungan yang dicapai bank sehingga kemungkinan suatu bank dalam kondisi bermasalah semakin kecil.

$$
\mathrm{ROA}=\frac{\text { earning before taxes }}{\text { Total assets }} \times 100 \%
$$

5) Liquidity / Likuiditas 
Likuiditas diproksikan dengan LDR (Loan to Deposit Ratio). LDR merupakan rasio kredit yang diberikan terhadap dana pihak ketiga, yang dimaksudkan untuk mengukur kemampuan bank dalam memenuhi pembayaran kembali deposito yang telah jatuh tempo kepada deposannya serta dapat memenuhi permohonan kredit yang diajukan tanpa terjadi penangguhan.

$$
\mathrm{LDR}=\frac{\text { kredit yang diberikan }}{\text { dana pihak ketiga }} \times 100 \%
$$

\section{HASIL PENELITIAN DAN PEMBAHASAN Hasil Penelitian}

Tabel 2. Statistik Deskriptif

\begin{tabular}{|c|c|c|c|c|c|}
\hline \multicolumn{6}{|c|}{ Statistik Deskriptif } \\
\hline & Kode & $\mathbf{N}$ & Mean & Std. Deviation & Std. Error Mean \\
\hline \multirow[t]{2}{*}{ CAR } & Umum & 50 & 16.4400 & 3.23980 & .45818 \\
\hline & Asing & 50 & 29.2400 & 34.74664 & 4.91392 \\
\hline \multirow[t]{2}{*}{ NPL } & Umum & 50 & 2.2200 & 2.48498 & .35143 \\
\hline & Asing & 50 & 1.5600 & 1.12776 & .15949 \\
\hline \multirow[t]{2}{*}{ NIM } & Umum & 50 & 6.0800 & 2.12699 & .30080 \\
\hline & Asing & 50 & 4.7400 & 2.03851 & .28829 \\
\hline \multirow[t]{2}{*}{ ROA } & Umum & 50 & 2.5200 & 1.23288 & .17436 \\
\hline & Asing & 50 & 2.9000 & 1.31320 & .18571 \\
\hline \multirow[t]{2}{*}{ LDR } & Umum & 50 & 69.7800 & 18.21559 & 2.57607 \\
\hline & Asing & 50 & 75.6600 & 28.09504 & 3.97324 \\
\hline
\end{tabular}

Sumber: Data Olahan (2014)

Adapun uraian masing-masing variabel adalah:

1. Nilai rata-rata CAR untuk Bank Nasional adalah 16.44 sedangkan Bank Asing memiliki nilai rata-rata sebesar 29.24. Nilai CAR yang lebih tinggi menunjukkan kemampuan bank asing menanggung resiko kerugian yang timbul lebih baik dari bank nasional.

2. Nilai rata-rata NPL untuk Bank Nasional adalah 2.22 sedangkan Bank Asing memiliki nilai rata-rata sebesar 1.56. Nilai NPL bank asing yang lebih rendah dari bank nasional menunjukkan semakin baiknya kemampuan bank asing dalam meminimalkan jumlah kredit bermasalah.

3. Nilai rata-rata NIM untuk Bank Nasional adalah 6.08 sedangkan Bank Asing memiliki nilai rata-rata sebesar 4.74. Nilai NIM bank nasional yang lebih tinggi dari bank asing mencerminkan meningkatnya pendapatan bunga atas aktiva produktif.

4. Nilai rata-rata ROA untuk Bank Nasional adalah 2.52 sedangkan Bank Asing memiliki nilai rata-rata sebesar 2.90. Nilai rata-rata ROA bank asing yang lebih tinggi mencerminkan peningkatan keuntungan yang dicapai, dan posisi bank yang semakin baik dari segi penggunaan aset.

5. Nilai rata-rata LDR untuk Bank Nasional adalah 69.78 sedangkan Bank Asing memiliki nilai rata-rata sebesar 75.66. Nilai rata-rata LDR bank asing yang lebih tinggi menunjukkan rendahnya kemampuan likuiditas bank asing sehingga kemungkinan bank dalam kondisi bermasalah yang semakin besar. 


\section{Pembahasan}

Tabel 3. Uji Beda Rata-rata

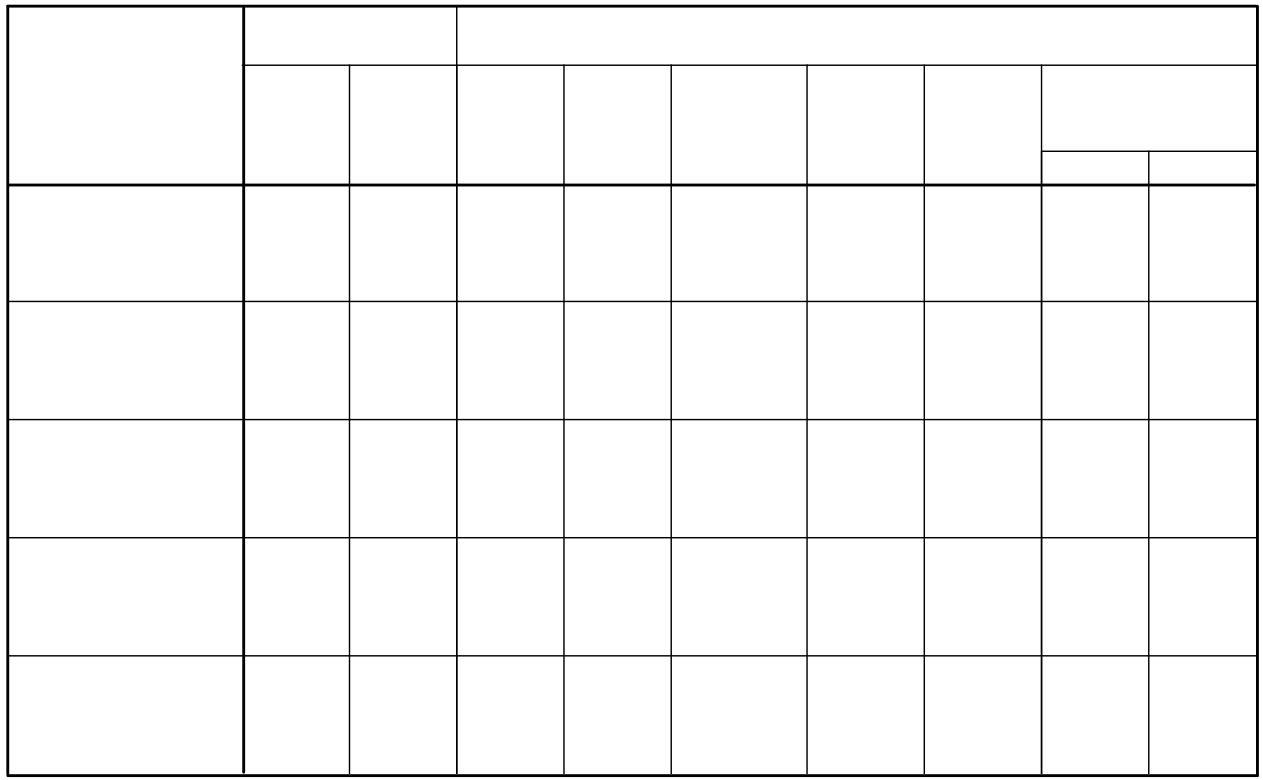

Sumber: Data Olahan (2014)

Berdasarkan statistik deskriptif dan pengujian nilai rata-rata atau uji beda rata-rata CAR menunjukkan bahwa, nilai CAR dari bank asing menunjukkan nilai sebesar 29.24 sedangkan CAR bank nasional menunjukkan nilai 16.44, sehingga hasil ini menunjukkan bahwa CAR bank asing memiliki nilai yang lebih tinggi dibandingkan dengan CAR bank nasional. Perbedaan nilai ini akan dikonfirmasi dengan melakukan pengujian perbedaan atas nilai ratarata. Berdasarkan uji beda rata-rata, uji $\mathrm{F}$ yang menunjukkan nilai signifikansi sebesar 0.001 yang berarti dapat disimpulkan bahwa persamaan varian tidak dapat diasumsikan (equal variances not assumed), sehingga uji perbedaan nilai rata-rata menunjukkan hasil signifikan $(<5 \%)$ dengan nilai signifikansi sebesar 0.012, dan dapat disimpulkan bahwa, perbedaan nilai CAR antara bank nasional dan bank asing adalah signifikan (dalam hal ini Ha diterima).

Berdasarkan statistik deskriptif dan pengujian nilai rata-rata atau uji beda rata-rata NPL menunjukkan bahwa, nilai NPL dari bank asing menunjukkan nilai sebesar 1.56 sedangkan NPL bank nasional menunjukkan nilai 2.22, sehingga hasil ini menunjukkan bahwa NPL bank asing memiliki nilai yang lebih rendah dibandingkan dengan NPL bank nasional. Perbedaan nilai ini akan dikonfirmasi dengan melakukan pengujian perbedaan atas nilai ratarata. Berdasarkan uji beda rata-rata, uji $\mathrm{F}$ yang menunjukkan nilai signifikansi sebesar 0.046 yang berarti dapat disimpulkan bahwa persamaan varian tidak dapat diasumsikan (equal variances not assumed), sehingga uji perbedaan nilai rata-rata menunjukkan hasil tidak signifikan ( $>5 \%$ ) dengan nilai signifikansi sebesar 0.092, dan dapat disimpulkan bahwa, perbedaan nilai NPL antara bank nasional dan bank asing adalah tidak signifikan (dalam hal ini Ha ditolak).

Berdasarkan statistik deskriptif dan pengujian nilai rata-rata atau uji beda menunjukkan bahwa, nilai NIM dari bank asing menunjukkan nilai sebesar 4.74 sedangkan NIM bank nasional menunjukkan nilai 6.08, sehingga hasil ini menunjukkan bahwa NIM bank asing memiliki nilai yang lebih rendah dibandingkan dengan NIM bank nasional. Perbedaan nilai ini akan dikonfirmasi dengan melakukan pengujian perbedaan atas nilai rata-rata. Berdasarkan uji beda rata-rata, uji $\mathrm{F}$ yang menunjukkan nilai signifikansi sebesar 0.986 yang 
berarti dapat disimpulkan bahwa persamaan varian dapat diasumsikan (equal variances assumed), sehingga uji perbedaan nilai rata-rata menunjukkan hasil signifikan $(<5 \%)$ dengan nilai signifikansi sebesar 0.002 , dan dapat disimpulkan bahwa, perbedaan nilai NIM antara bank nasional dan bank asing adalah signifikan (dalam hal ini Ha diterima).

Berdasarkan statistik deskriptif dan pengujian nilai rata-rata atau uji beda menunjukkan bahwa, nilai ROA dari bank asing menunjukkan nilai sebesar 2.90, sedangkan ROA bank nasional menunjukkan nilai 2.52, sehingga hasil ini menunjukkan bahwa ROA bank asing memiliki nilai yang lebih tinggi dibandingkan dengan ROA bank nasional. Perbedaan nilai ini akan dikonfirmasi dengan melakukan pengujian perbedaan atas nilai rata-rata. Berdasarkan uji beda rata-rata, uji $\mathrm{F}$ yang menunjukkan nilai signifikansi sebesar 0.787 yang berarti dapat disimpulkan bahwa persamaan varian dapat diasumsikan (equal variances assumed), sehingga uji perbedaan nilai rata-rata menunjukkan hasil tidak signifikan ( $>5 \%)$ dengan nilai signifikansi sebesar 0.139 , dan dapat disimpulkan bahwa, perbedaan nilai ROA antara bank nasional dan bank asing adalah tidak signifikan (dalam hal ini Ha ditolak).

Berdasarkan statistik deskriptif dan pengujian nilai rata-rata atau uji beda menunjukkan bahwa, nilai LDR dari bank asing menunjukkan nilai sebesar 75.66, sedangkan LDR bank nasional menunjukkan nilai 69.78, sehingga hasil ini menunjukkan bahwa LDR bank asing memiliki nilai yang lebih tinggi dibandingkan dengan LDR bank nasional. Perbedaan nilai ini akan dikonfirmasi dengan melakukan pengujian perbedaan atas nilai rata-rata. Berdasarkan uji beda rata-rata, uji $\mathrm{F}$ yang menunjukkan nilai signifikansi sebesar 0.137 yang berarti dapat disimpulkan bahwa persamaan varian dapat diasumsikan (equal variances assumed), sehingga uji perbedaan nilai rata-rata menunjukkan hasil tidak signifikan ( $>5 \%$ ) dengan nilai signifikansi sebesar 0.217, dan dapat disimpulkan bahwa, perbedaan nilai ROA antara bank nasional dan bank asing adalah tidak signifikan (dalam hal ini Ha ditolak).

Hasil rasio-rasio keuangan dari bank asing yang lebih baik dari bank nasional disebabkan oleh karena adanya hasil pengelolaan manajerial yang lebih baik dari segi permodalan, kualitas aktiva produktif, manajemen, rentabilitas, dan likuiditas yang diproksikan dengan CAMEL.

Penelitian ini mendukung hasil penelitian sebelumnya oleh Rumondor (2013) yang menyimpulkan bahwa rasio CAMEL mempunyai pengaruh yang signifikan terhadap kinerja keuangan perbankan.

\section{PENUTUP}

\section{Kesimpulan}

Kinerja bank asing masih lebih baik daripada bank nasional, hal ini dapat terlihat dari :

1. Rasio CAR bank asing yang menunjukkan nilai 29.24 lebih tinggi dibandingkan dengan CAR bank nasional yang menunjukkan nilai 16.44. Semakin tinggi CAR maka semakin baik kemampuan bank untuk menanggung resiko dari setiap kredit atau aktiva produktif yang beresiko.

2. Rasio NPL bank asing yang menunjukkan nilai 1.56 sedangkan NPL bank nasional yang menunjukkan nilai 2.22. Semakin rendah NPL semakin baik kemampuan bank dalam mememinimalkan jumlah kredit bermasalah.

3. Rasio NIM bank asing yang menunjukkan nilai 4.74 sedangkan NIM bank nasional yang menunjukkan nilai 6.08. Semakin besar NIM akan membantu meningkatkan pendapatan bunga atas aktiva produktif.

4. Rasio ROA bank asing yang menunjukkan nilai 2.90 sedangkan ROA bank nasional yang menunjukkan nilai 2.52. Semakin besar ROA semakin besar pula tingkat keuntungan yang dicapai, dan semakin baik posisi bank dari segi penggunaan aset. 
5. Rasio LDR bank asing yang menunjukkan nilai 75.66 sedangkan LDR bank nasional yang menunjukkan nilai 69.78. Semakin rendah LDR, semakin rendah kemampuan likuiditas bank sehingga kemungkinan bank dalam kondisi bermasalah semakin besar.

Berdasarkan hasil pengujian perbandingan nilai rata-rata, perbedaan signifikan antara kinerja bank asing dengan bank nasional terletak pada rasio CAR dan NIM.

\section{Saran}

Berdasarkan hasil pengujian ditemukan bahwa rasio-rasio CAMEL pada Bank Nasional masih belum terlalu baik dibandingkan dengan rasio-rasio yang dimiliki oleh Bank Asing. Sehingga disarankan kepada pihak manajemen Bank Nasional untuk lebih memperhatikan pengelolaan yang ada pada organisasinya agar dapat meningkatkan kinerja manajerialnya.

Lebih lanjut, diharapkan penelitian ini dapat menjadi referensi bagi penelitian selanjutnya yang berada di bidang yang sama, serta dapat dikembangkan lebih lanjut model penelitiannya agar dapat memberikan kontribusi yang lebih mendalam atas peningkatan kinerja manajerial khususnya yang berada di pihak Bank Nasional.

\section{DAFTAR PUSTAKA}

Amalia, Alia. 2010. Pengaruh CAR, NPL, NIM, BOPO, LDR, dan PPAP Terhadap Kinerja Rentabilitas Bank (Studi Kasus Pada Bank Devisa dan Bank Non Devisa Tahun 20042008). Skripsi Fakultas Ekonomi. Universitas Diponegoro. Semarang.

Bank Indonesia. Laporan Keuangan Publikasi Bank. www.bi.go.id diakses Mei 082014. Manado.

Clorinda, Karunia. 2013. Analisis Pengaruh Rasio Capital, Asset Quality, dan Liquidity Terhadap Kinerja Keuangan Pada Sektor Perbankan Yang Terdaftar di Bursa Efek Indonesia Periode 2007-2011. Jurnal Ilmiah. Universitas Surabaya. Surabaya.

Djiwandono, J, Soedrajad. 2002. Masalah Burden Sharing Pembiayaan BLBI antara pemerintah dan BI. File : //A: Pacific Link-Kolom Pakar.

Hutagalung., Djumahir., Ratnawati. 2011. Analisa Rasio Keuangan terhadap Kinerja Bank Umum di Indonesia. Jurnal Ekonomi dan Bisnis. Volume 11, No.1. Unviersitas Brawijaya. Malang.

Handayani, Puspita. 2005. Analisa Perbandingan Kinerja Bank dengan Rasio Keuangan. Tesis Magister Manajemen. Universitas Diponegoro. Semarang.

IDX. Laporan Keuangan Publikasi. www.idx.co.id diakses Mei 08 2014. Manado.

Kasmir. 2012. Manajemen Perbankan Edisi Revisi. PT Raja Grafindo Persada. Jakarta.

Machfoedz.,Mas'ud.,Payamta. 1999. Pengaruh Krisis Moneter pada Efisiensi Perusahaan Publik di Bursa Efek Jakarta. Jurnal Ekonomi dan Bisnis Indonesia. Volume 14, No.1. Hal 37-49.

Machfoedz, Ircham. 2006. Metodologi Penelitian. Fitrimaya. Yogyakarta.

Nasser.,Etty dan Aryati.,Titik. 2005. Model Analisis CAMEL untuk Memprediksi Financial Distress pada Sektor Perbankan yang Go Public. JAAI. Volume 4, No.2. Hal 111127. 
Peraturan Bank Indonesia Nomor 6/10/PBI/2004 tanggal 12 April 2004. Perihal Peringkat Komposit Setiap Faktor. Bank Indonesia. Jakarta.

Prasnanugraha, Ponttie. 2007. Analisis Pengaruh Rasio-rasio Keuangan Terhadap Kinerja Bank Umum di Indonesia. Tesis Magister Sains Akuntansi. Universitas Diponegoro. Semarang.

Republik Indonesia. Undang-Undang No. 10 tahun 1998 tentang Perbankan. Jakarta.

Rumondor, Risca. 2013. Perbandingan Kinerja Keuangan Bank MANDIRI, BNI, dan BRI Yang Terdaftar di Bursa Efek Indonesia. Jurnal EMBA. Universitas Sam Ratulangi. Manado.

Soendoro.,Hayati. 2001. Kinerja Keuangan Bank-Bank Beku Operasi, Take Over, Rekapitulasi dan Sehat tahun 1992-1998. Ventura. Volume 4, No.2, Hal 97-101.

Sunggono, Bambang. 2005. Pengantar Hukum Perbankan. CV Mandar Maju. Jakarta.

Surat Edaran Bank Indonesia Nomor 6/23/Intern DPNP tgl 31 Mei 2004. Perihal Pedoman Sistem Penilaian Tingkat Kesehatan Bank (CAMELS Rating). Bank Indonesia. Jakarta.

Surat Edaran Bank Indonesia Nomor 3/30/DPNP tanggal 14 Desember 2001. Lampiran Pedoman Perhitungan Rasio Keuangan. Bank Indonesia. Jakarta.

Suyatno, Thomas. 2007. Kelembagaan Perbankan. PT. Gramedia Pustaka Utama. Edisi Ketiga. Jakarta.

Utomo, Priyo. 2008. Pengaruh Non Performing Loan Terhadap Kinerja Keuangan Bank Berdasarkan Rasio Likuiditas, Solvabilitas, dan Profitabilitas Pada PT Bank Mandiri (PERSERO), Tbk. Tesis Magister Manajemen. Universitas Gunadarma. Jakarta. 